\title{
The Significance of Universities' Vocational Guidance in University Student Employability Cultivation
}

\author{
Yongmei $\mathrm{Hao}^{1}$, Nan $\mathrm{Yao}^{1}$ \\ ${ }^{1}$ Nanjing University of Information Science and Technology, Nanjing, 210044, China
}

Keywords: Vocational guidance, Employability, University students

\begin{abstract}
Vocational guidance is a long-term work, and it plays a very important role in enhancing the university student employability by means of guidance, navigation, assistance and bridging. However, the present vocational guidance by universities is not satisfactory in the aspects of guidance form, method, information, strength and personnel composition. This paper starts from the significance and ways of universities' vocational guidance in enhancing university student employability, and puts forward the work ideas of establishing the 3D vocational guidance platform, building and improving the "full-process, professional, market-oriented, and modernized" vocational guidance system in universities, constructing the "developmental , innovative and all-round" vocational guidance platform, and perfecting the vocational guidance system in universities.
\end{abstract}

\section{Introduction}

Employability $^{[1]}$ means the personal ability to obtain and keep a job and also have a good job performance after the learning process. The university student employability has become an important and core topic in many countries. Generally, employment focuses on whether university graduates can find a job and enter the workplace to provide services within a specified short period (3 months, 6 months); in contrast, employability focuses on the long-term career development in a professional field, which may be even converted to the cultivation of work ability in different professional fields. To fundamentally solve the difficulty in university student employment, the objective of university student employment policies must be transformed from improving the "employment rate" into improving the "employability", and it is also required to carry forward the employment guidance and dual-option will policies at the time of graduation into the process of higher education, to establish the employment system where the university student employability is taken as the core, the government, universities and employers cooperate closely with each other, and the integral improvement is adopted ${ }^{[2]}$.

The university period is a complete and systematic transition and preparation stage for university students before they move towards their work posts. Universities' vocational guidance ${ }^{[3]}$ will facilitate university students' understanding of social employment situation and current employment condition, and is the process to make them know their own vocational interests, vocational abilities and personal characteristics; the use of vocational evaluation and analysis, investigation, and psychological measurement methods will make university students rationally plan their future development, comprehensively improve their qualities and abilities, and intentionally enhance their employability in the four-year study in universities. Vocational guidance is very necessary and important for enhancing university students' employability, shall be put on the agenda and become an urgent thing.

\section{Problems in present vocational guidance in our universities}

Currently, the serious problem of mismatching exists in the current situation of vocational guidance in our universities and the cultivation of university student employability, and many other problems in universities' vocational guidance need to be solved urgently[4].

In the aspect of vocational guidance form, the skills training is much less than traditional teaching. Currently, most universities carry out the vocational guidance by means of course teaching (career 
planning, employment guidance, situation and policy education) or giving lectures; thus the vocational guidance form is simplex. As for cultivation of vocational skills, many universities are restricted by conditions and personnel, consequently fail to organize the group guidance and quality development, and rarely emphasize the cultivation of skills in career planning, information collection and processing, career decision-making, etc.

In the aspect of vocational guidance method, the individualized guidance is much less than the universal guidance. At present, many universities fail to list the vocational guidance into the teaching plan and are short of vocational guidance textbooks directed against the characteristics of universities. In the actual guidance, more introduction is made to common problems in vocational guidance such as vocational environment, job selection activities, employment situation, etc., while less introduction is made to individualized problems such as how to cultivate students' abilities of innovation, creativity, entrepreneurial ability, career development, etc.; some universities even restrict the vocational guidance within their campuses, leading to the lack of training students' occupational experience.

In the aspect of vocational guidance information, the occupational information is much less than the employment information. Currently, most universities focus on introduction to employment information such as employment policy, resume preparation, employment system, etc., and rarely mention the contents in the aspects of self-value assessment and exploration in the career development stage, comprehensive quality and ability required for specialized courses, the matching of appropriate practice platform, the significance of career planning and university students' occupational planning, etc.

In the aspect of vocational guidance strength, the situational guidance is much less than the theoretical guidance. Currently, many universities indeed have opened the vocational guidance in the lower-grade stage, and some universities even have opened the career planning course in the freshman year and also opened the employment guidance course in the senior year; however, such guidance just stays on the surface without going into it deeply. For example, the training about interview skills just involves the theory teaching in classroom, lacking the corresponding actual interview simulation link and making it difficult for students to understand and grasp.

In the aspect of vocational guidance personnel, professionals are much less than school teachers. As for the composition vocational guidance personnel, the main forces participated in students' vocational guidance in universities are currently the deputy secretaries and instructors responsible for student work; as they have a lot of daily routine works and lack the experience in vocational guidance, their most understanding of vocational guidance comes from indirect channels such as the experience of other persons, theories in textbooks, etc., other than from the direct channel of their own occupational experience; therefore, the vocational guidance by deputy secretaries and instructors responsible for student work is obviously insufficient. The urgent thing for universities is to give full play to in-school full-time teachers' guidance through classroom teaching and also integrate excellent schoolfellows and social resources, so as to let more personnel with occupational experience join in the vocational guidance in universities.

\section{The significance of universities' vocational guidance on enhancing university student employability}

Vocational guidance in universities is a educational process; in essence, it belongs to the category of ideological education, and is an important integral part of school education. Essentially, vocational guidance is to provide students with education in career awareness, goals and ethics, help them to understand the career information, provide them with employment consultation and service, and let them learn how to design and select, so as to achieve the scientific person-job matching and realize the personal and social values. It has very important theoretical significance and profound practical significance for the government, universities, employers and graduates. 


\section{Guiding role: Vocational guidance will help university students to set up a scientific job-hunting view}

Currently, university graduates have three mistakes in the aspect of employment views; firstly, some graduates have no confidence in employment and often "accept whatever jobs" in the employment process; secondly, some graduates have excessive confidence in employment and often "hope to get jobs that are beyond their grasp"; thirdly, some graduates have the herd behavior and often "go with the tide" in the employment process. The aforesaid wrong employment views will have a adverse influence on university students' job-hunting process, and are very different from the scientific job-hunting view advocated in the society. The job-hunting view is an important content in vocational guidance in universities, with the purpose of guiding university students to set up a correct employment view, life view, world view and value view, help them to correctly understand the employment situation, environment and means as well as occupational condition, and assist them in rationally treating the employment. Meanwhile, the vocational guidance also changes the graduates' prejudice of working only in big cities and public institutions, guides and encourages university graduates to join in Western Plan, "Three Supports and One Assistance" Plan, North Jiangsu Plan, and Village Officials Plan, and makes full use of relevant national policies to provide graduates with more employment channels and job-hunting opportunities. By analysis on typical cases, the vocational guidance makes students understand the complementary relation of employment selection with their interests and abilities.

\section{Navigating role: Vocational guidance is beneficial to enhancing students' abilities in dealing with the social competition.}

Since the popularization of higher education in 1999, there are several millions of graduates from universities every year; thus, students need to not only grasp a solid basic professional knowledge, but also combine the professional knowledge structure with the comprehensive application ability, so as to become all-round talents and stand out from the crowd of graduates. One of the important objectives of the vocational guidance in universities is to make students have their clear career goals and development directions by virtue of the professional planning guidance, carry out positive and effective actions based on this, receive targeted cultivation and trainings in comprehensive quality and ability, practice skills, knowledge structure, etc., comprehensively improve their abilities, enhance their employment competitiveness and obtain success in job hunting.

\section{Assisting role: Vocational guidance is favorable to guiding university students in correctly understanding themselves and mining their potentials.}

One of the important links of vocational guidance course is the self-understanding. By analyzing the relationship between temperament and occupation, personality and occupation, interest and occupation, using the comparison method-self-understanding from the relation between myself and people, the empirical method-self-understanding from the relation between myself and things, and the self-questioning method-self-understanding from the relation between me and myself, and in virtue of professional assessment tools, the vocational guidance makes university students comprehensively analyze themselves from all aspects, fully understand their own temperaments, personalities, interests, advantages and disadvantages, learn what they are suitable for and what they can do. Bridging role: Vocational guidance is beneficial to university students' future development.

University students' vocational guidance process is also the education attaining process; the job hunting process is the process of communicating with employers; in this process, students not only obtain the results about whether they are employed or not, but also find their own disadvantages and understand employers' requirements on students' occupational qualities. Employment is just the first step towards the life career, rather than the employment just for getting a job; students need to understand that they obtain success in their careers by selecting appropriate job posts and fully achieve their life value. Therefore, the significance of vocational guidance in universities lies in the full process of university students' development. 
Table 1. Investigation and Statistics about the Influence of Vocational Guidance on Personal Life

\begin{tabular}{|c|c|c|c|c|c|}
\hline \multirow[b]{2}{*}{ Туре } & \multicolumn{3}{|c|}{ Objectives before 25 years } & \multirow{2}{*}{$\begin{array}{l}\text { Whether } \\
\text { objects are } \\
\text { changed } \\
\text { within the } 25 \\
\text { years }\end{array}$} & \multirow[b]{2}{*}{$\begin{array}{l}\text { Results of objective setting } \\
\text { personnel after } 25 \text { years }\end{array}$} \\
\hline & $\begin{array}{l}\text { Whether to } \\
\text { have } \\
\text { objectives }\end{array}$ & $\begin{array}{l}\text { Clear or } \\
\text { unclear } \\
\text { objectives }\end{array}$ & $\begin{array}{l}\text { Long-term } \\
\text { or } \\
\text { short-term } \\
\text { objectives }\end{array}$ & & \\
\hline $\begin{array}{l}3 \% \text { of the } \\
\text { people }\end{array}$ & Yes & Clear & Long-term & $\begin{array}{l}\text { Never } \\
\text { changed }\end{array}$ & $\begin{array}{l}\text { Becoming entrepreneurs, } \\
\text { industry leaders and social } \\
\text { elites }\end{array}$ \\
\hline
\end{tabular}

\begin{tabular}{|c|c|c|c|c|c|}
\hline $\begin{array}{l}10 \% \text { of the } \\
\text { people }\end{array}$ & Yes & Clear & Short-term & Changed & $\begin{array}{l}\text { Becoming specialized talents } \\
\text { in different industries and } \\
\text { living in the middle and upper } \\
\text { levels }\end{array}$ \\
\hline $60 \%$ & Unclear & Unclear & / & / & $\begin{array}{l}\text { Living smoothly and } \\
\text { having ntably, } \\
\text { achievements }\end{array}$ \\
\hline $\begin{array}{l}27 \% \text { of the } \\
\text { people }\end{array}$ & No & 1 & I & I & $\begin{array}{l}\text { Living in the bottom level of } \\
\text { the society, being often }\end{array}$ \\
\hline
\end{tabular}

Data source: Bian Huimin, University Student Career Planning, Southwest University of Finance and Economics Publishing House, edition 2007

\section{Ways of strengthening the vocational guidance and enhancing university student employability}

\section{Establishing the student-oriented 3D vocational guidance platform to enhance university students' comprehensive qualities and employability}

Universities need to gradually establish the 3D university student vocational guidance platform that covers information platform, individual consultation, group guidance, classroom teaching and extracurricular practice. Firstly, implement the individual consultation and classified training to strengthen the employment skills. Different university students have different personalities, temperaments, interests and hobbies; thus, it is required to carry out the targeted vocational guidance to effectively strengthen students' core vocational competitiveness. Secondly, attach importance to classroom teaching and set up the teaching philosophy that centers on employability cultivation. Specifically, the teaching plan, course guidance, after-class training and other links need to center on the employability cultivation, with the purpose of enhancing university students' employability in the three stages of "employment, competence and development". Thirdly, organize group guidance and extracurricular practice activities, such as simulated interview, employment skill competition, university student career design competition, resume preparation training and competition, postgraduate entrance exams experience exchange meeting, university student employment psychology training, etc., to effectively strengthen students' business skill and quality training and achieve the purpose of cultivating practical and professional skilled talents. Fourthly, strengthen the information platform construction, the employment market exploitation, and the process of information networking for graduate employment, so as to establish the information networking platform that integrates the policy announcement, information publishing, online recruitment, consultation guidance, remote interview, etc., and to set up the extensive vocational guidance and consultation service network system. 


\section{Establishing and improving the full-process, professional, market-oriented, and modernized vocational guidance system in universities}

Firstly, establish the full-process guidance system that extends from freshman year to senior year. The key point in the freshman year is to strengthen university students' understanding of the importance and urgency of career planning; key point in sophomore and junior years is to assist students in correctly understanding themselves and in thinking how to find the balance point when they make a selection between employment and taking part in postgraduate entrance exams; the key point in senior year is to complete the employment guidance in a well manner. Secondly, establish a professional employment guidance team that can be expanded to HR supervisors of enterprises and public institutions, excellent schoolfellows, employment experts, psychologists and social successful people, who can provide graduates with relevant information, consultation, guidance and training services. Thirdly, universities need to actively combine with enterprises with the work ideas of "going out and inviting others to come in" for the vocational guidance. On one hand, enterprises can participate in teaching planning and course setting of universities to make the contents of courses in universities connected with the society; on the other hand, universities arrange students to have a visit and internship in enterprises in the sophomore and junior years, to make students understand the importance of team work in the learning stage, discover the insufficiency of theoretical knowledge and practice skills as soon as possible, strengthen their motivation to learn skills, and make full preparation for future job selection. Finally, the vocational guidance work is a dynamic work, thus it shall closely follow the trend of the times and keep pace with the times; it is also required to exploit information-based guidance channels such as network and mobile platform, and timely adjust the guiding contents and skills based on employers' requirements, so as to make the knowledge grasped by students conform to the development of the times.

\section{Establishing the "developmental, innovative and all-round" vocational guidance platform}

Imitate the vocational guidance concepts and methods of foreign advanced universities and combine the actual situation of the vocational guidance work in our universities to gradually form the vocational guidance theory system that is suitable to the Chinese situation; the writer thought that its strengthening and improvement shall be achieved from the following aspects. Firstly, explore the "developmental" vocational guidance mode. Universities need to grasp the rules and characteristics of the vocational guidance work, accumulate, analyze and summarize typical cases and form research topics, so as to improve the theoretical level of vocational guidance and form the vocational guidance modes containing the characteristics of universities. Secondly, establish the "innovative" vocational guidance platform. Universities need to actively implement relevant national special projects for promoting the university graduate employment and strengthen the policy propaganda and promotion to gradually guide students to achieve their life values in the roots level, pay attention to university students' individualized development, carry out career planning guidance and "one-to-one" consultation, and provide them with targeted assistance in the psychological, academic, job-hunting, living and other aspects, so as to help students to set customized career development goals and facilitate their satisfied employment. Thirdly, cultivate the "all-round" university graduate employment market. In some extent, graduate employability decides the talent cultivation quality of universities; thus, universities need to insist on the student-oriented principle, innovate the working ideas and establish the vocational guidance systems containing their characteristics. Universities also need to give play to their technical advantages to promote the linkage among scientific research, industry and student work, actively establish a long-term cooperative relationship with large and medium-sized enterprises, talent institutions of governments at all levels and other universities so as to achieve the information intercommunication.

\section{Conclusion}

The employment work is an important content in the school work, and is a livelihood project that concerns the social stability; the career development and employment guidance of university students 
are important educational links in talent cultivation in universities, and the significance of vocational guidance for students in universities is not just to "find a job"; more importantly, it is to enhance students' competitiveness in the aspect of career choice and to improve students' "employability"; the big difficulty in university graduate employment can be gradually solved only by completing the vocational guidance as a systematic project and strengthening each stage of vocational education and guidance for university students.

\section{Acknowledgments}

This paper is a guiding project for philosophy and social science research in Colleges and Universities in Jiangsu; the project name is: Research on Innovation of university Career-creating Talent Cultivation Mode with Industry Characteristics, and the project number is: 2012SJDFDY053. It is also a key determined project for special research on entrepreneurship of Nanjing University of Information Science \& Technology in 2014; the project name is: Research on Hierarchy Analysis Method Based University Graduate Employability Assessment System, and the project number is: 2014NUISTJCYA03.

\section{References}

[1] Zheng Xiaoming. Discussion on "Employability". Journal of China Youth University of Political Studies, 2002 (5): 91-92.

[2] Education Transformation- Employability is More Important than Employment Rate. Occupation, 2010 (4).

[3] Huang Huang. A Tentative Study on Facilitating University Graduate Employment by Vocational Guidance. Youth \& Society, 2013 (4): 36-37.

[4] Training and Employment Division of Ministry of Labor and Social Security, China Employment Training Technical Instruction Center. Innovative Occupation Guidance -New Concept. Beijing: China Labor and Social Security Press, 2005. 